\title{
S7 Fig
}

A
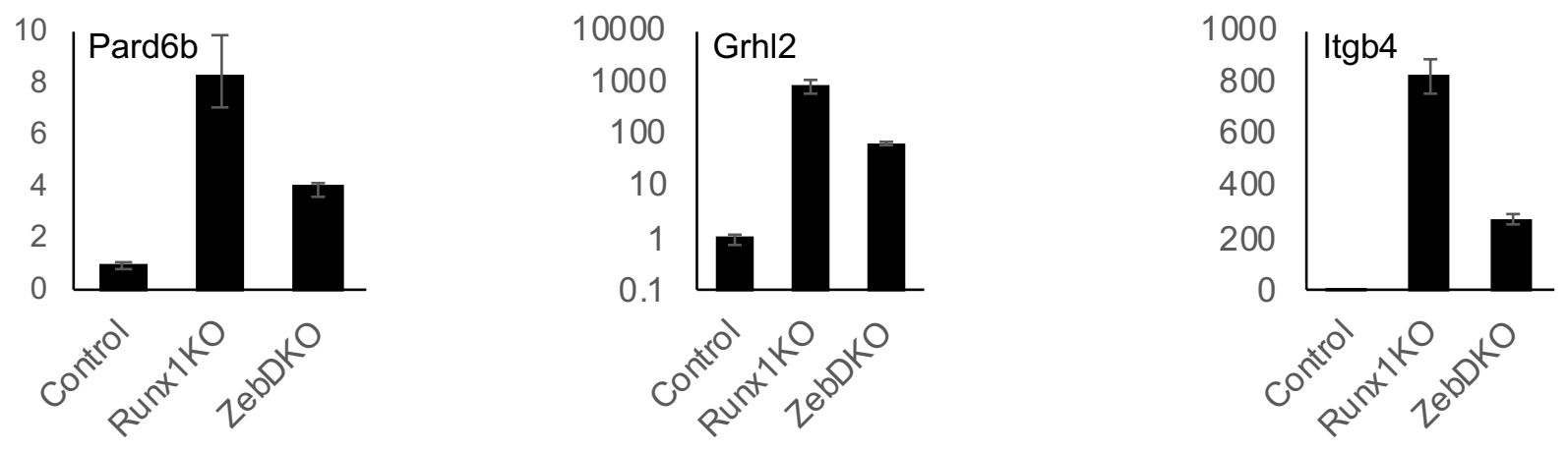

B
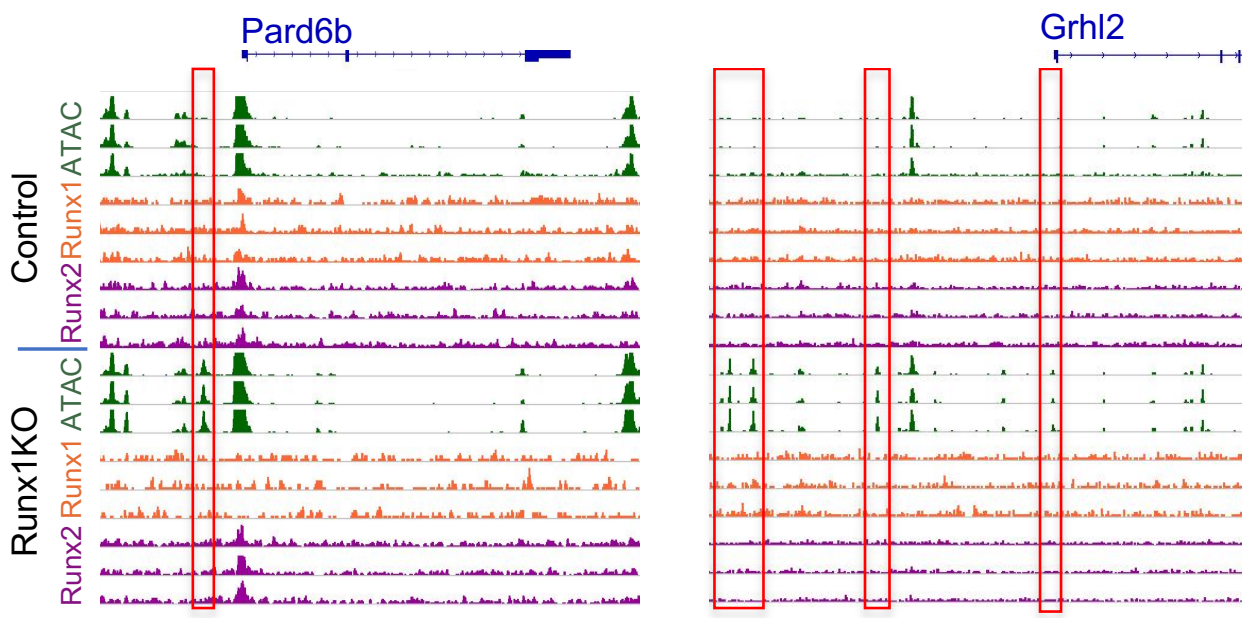

Itgb4

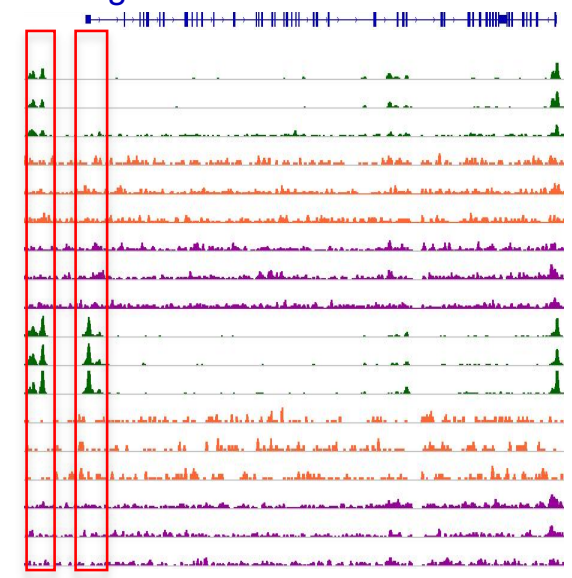

RNA Expression Z-score

D

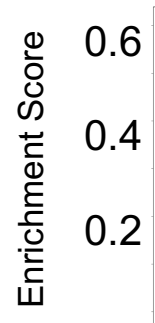

Runx1KO 2 fold Increased Genes
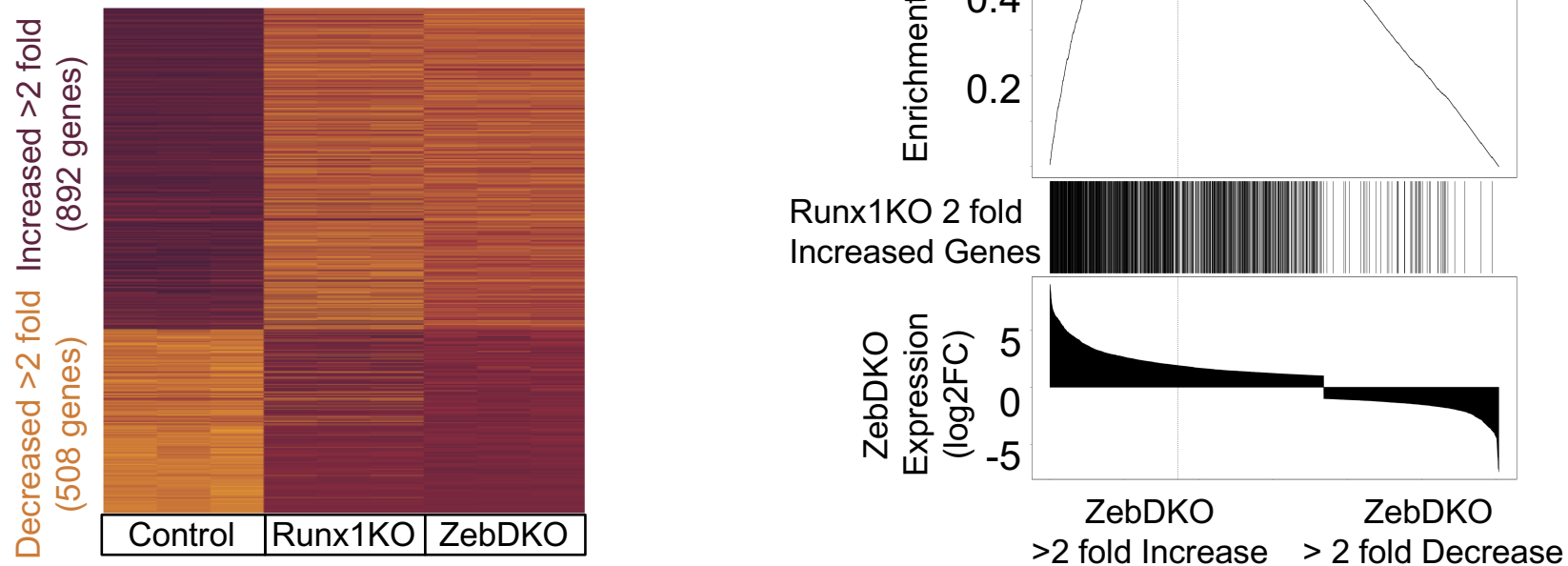